\title{
The Effect of Date and Pattern of Sowing on Growth, Productivity and Technological Characters of Cotton (Gossypium barbadense L.) Variety Giza 86
}

\author{
Mahmoud H. Abd El-Moneim, Mohsen A. Omar, Sami S. EL-Tabbakh and Ali I.Nawar ${ }^{1}$
}

\begin{abstract}
Two field experiments were conducted during the 2013 and 2014 summer seasons to investigate the effect of planting dates and planting patterns on productivity and quality characters of Egyptian cotton cultivar Giza 86 (Gossypium barbadense L.). Effects of planting date were more pronounced on the studied phenological characters, yield and yield components than the planting patterns. The fiber technological traits including micronaire-reading, fiber maturity, fiber upper half mean length (UHML), uniformity index (UI), short fiber (SF) and fiber strength (Str.) were least affected by either planting dates or planting patterns. Results suggest that growing cotton on the $1^{\text {st }}$ of April is more suitable than delayed sowing for the cultivar Giza 86 and that the standard sowing of seeds on one side of the ridge, in hills $25 \mathrm{~cm}$ apart, resulted in better growth characters and highest yields. Also growing cotton on the wide ridges of the preceding wheat crop is not recommended as it resulted in reduction in yield and its components.
\end{abstract}

Keywords: Cotton, Planting dates, Planting patterns and yield components.

\section{INTRODUCTION}

Cotton is the most important fiber crop in the world and in Egypt. In Egypt, it plays a prominent role in agricultural production, industry and national economy. Egyptian cotton used to be the main source of cash income for more than half a million households of farmers (Showler et al., 2005 and Aasim et al., 2008). At the present time, cotton is facing a serious problem, where production costs per unit area have rapidly increased while price is usually fixed and determined by the government (El-Tabbakh, 2001), which forced the majority of cotton growers to shift to growing other more profitable crops like maize or rice. This resulted in reduction in the cotton growing area by $36 \%$ to drop to 245 thousand faddan in 2015 compared to about 367 thousand faddan in 2014. One of the major reasons for the reduction in cultivated area was the decline of productivity, which fell to only four kantars per faddan, compared to about seven kantars per faddan in previous seasons (Ahmed et al., 2008 and Ahmed et al., 2013). Hence, it is necessary to find a way to decrease cotton production costs and increase yield per unit area, besides maintaining the fiber quality.

\footnotetext{
${ }^{1}$ Crop science department, Faculty of Agriculture, Alexandria University. Received July 10, 2017, Accepted July 26, 2017.
}

The high value of clover preceding cotton tempted farmers to delay cotton growing to the beginning of May, instead of the recommended $1^{\text {st }}$ of April growing date. The main question raised in the present study was concerned with the negative effects of delaying cotton planting to May, because previous studies recommended that the best planting date in Egypt should be before mid-March (Shalaby, 1972, El-Hariry, 1986 and Shafshak et al., 1987). Another concern raised in this study was growing cotton on wide ridges. A trend gaining interest by farmers namely; growing cotton late in summer on the same wide ridges of the preceding wheat crop. A method presumably lowering the expenses of land preparation, decreasing irrigation requirements, and permitting the growth of cotton following wheat. However, spacing between cotton plants has been shown to have important effects on plant growth and yield characters according to Baker, (1976) and Nadeem et al.(2010). Planting dates and planting pattern, are considered important factors for increasing seed cotton yield per unit area (Din et al., 2004, Dong et al., 2006 and Barradas and Lopez-Bellido et al., 2009).

The aim of the present study was to investigate the possibility of growing cotton on wide ridges with different patterns to adapt that for growing after wheat crop. Also, to evaluate the effect of sowing dates on seed cotton yield and fiber properties.

\section{MATERIALS AND METHODS}

Two field experiments were conducted during the 2013 and 2014 summer seasons at the Agriculture Research Station, Alexandria University. The Egyptian cotton cultivar Giza 86 (Gossypium barbadense L.) was employed in this study. A split-plot in randomized complete block design, with three replicates, was used in the two experiments.

The main plots were assigned to three sowing dates: April $1^{\text {st }}\left(D_{1}\right)$, April $15^{\text {th }}\left(D_{2}\right)$ and May $2^{\text {nd }}\left(D_{3}\right)$ in the two seasons. The sub plots were devoted to three sowing patterns $(\mathrm{P})$ and maintaining a fixed plant population of 56000 plants/faddan as follows:

1-On one side of the ridge: "60 $\mathrm{cm}$ " between ridges, in hills $25 \mathrm{~cm}$ apart and thinned to two plants/hill (P1). 
2-On both sides of wide ridges: "120 cm", in hills $25 \mathrm{~cm}$ apart and thinned to two plants/hill (P2).

3-On both sides and the middle of wide ridges: "120 $\mathrm{cm}^{\prime \prime}$ in hills $33 \mathrm{~cm}$ apart and thinned to two plants/hill (P3).

Seeds were hand sown on the specified dates. The area of main plots and sub-plots were made up $64.8 \mathrm{~m}^{2}$ and $21.6 \mathrm{~m}^{2}$, respectively, where the sub-plot was of 12 ridges or 6 wide ridges of length 3.0 meters.

Phosphorus fertilizer dose of $23.25 \mathrm{~kg} \mathrm{P}_{2} \mathrm{O}_{5}$ per fad. (54 kg $\mathrm{P}_{2} \mathrm{O}_{5}$ per ha) in the form of calcium monophosphate $\left(15.5 \% \quad \mathrm{P}_{2} \mathrm{O}_{5}\right)$ was added and mixed during seed bed preparation. Nitrogen fertilization was applied at the rate of $60 \mathrm{~kg} \mathrm{~N}$ per fad. (144 N per ha), in the form of ammonium nitrate $(33.5 \% \mathrm{~N})$, in three equal doses. The first dose was applied after thinning, while the second and the third doses were added at four weeks intervals. All the other agricultural practices (cultivation, thinning, weeding, pest control, irrigation, etc.) were carried out as recommended by the Ministry of Agricultural and Land Reclamation (MALR) for the cultivar in the farm zone. Seed cotton picking was made by hand on two stages, at $60 \%$ boll opening and one month later.

Five plants were randomly chosen from the eight inner (guarded) ridges of each sub plot and the following characters were recorded on these plants:

1. Phenological characters: Plant height $(\mathrm{cm})$, position of the first vegetative node from soil surface $(\mathrm{cm})$, number of vegetative branches/plant, position of the first fruiting node from soil surface $(\mathrm{cm})$ and earliness index, calculated as the number of bolls from the first picking/ total number of bolls X 100 .

2. Yield characters: Seed cotton yield/plant (g), number of bolls/plant, and boll weight (g).
3.Technological characters: Micronaire reading (Mic.), Maturity ratio (Mat.), fiber upper half mean length (UHML) measured in mm, uniformity index percent (UI), fiber strength (Str.), measured in $\mathrm{g} / \mathrm{tex}$ and percent short fiber $(\mathrm{Sf})$.

Statistical analysis was carried out according to Gomez and Gomez (1984) using SAS (Statistical Analysis System) version 9.3 (2007).

\section{RERSULTS AND DISCUSSION}

\section{I- Phenological characters:}

Analysis of variance indicated that sowing date significantly affected all plant morphological characters including plant height, position of the first vegetative node and number of vegetative branches/plant (Table 1) and position of the first fruiting node and earliness index (Table 2), in both growing seasons. Planting patterns, on the other hand, had significant effects only on position of the first vegetative node and number of vegetative branches/pant in the 2013 growing season (Table 1) and earliness in both seasons (Table 2). The interaction between sowing dates and plant patterns was significant for all phenological traits (Tables $2 \& 4$ ).

In general, it could be observed that late sowing resulted in reduced plant height, lower position of the first vegetative node and first fruiting node, reduced number of vegetative branches/plant and decreased earliness index (Tables $1 \& 3$ ).

Planting patterns had very limited effects on all studied phenological characters. Regarding the interaction between sowing dates and planting patterns, it could be observed that the lowest positions of the first vegetative node $(12.53$ and $12.20 \mathrm{~cm})$ and fruiting node $(17.13$ and $17.60 \mathrm{~cm})$ were recorded for the late sowing date with the $\mathrm{P}_{2}$ and $\mathrm{P}_{3}$ planting patterns, respectively, in 2013 and any of the three planting patterns for position of the first fruiting node in 2014.

Table 1. Mean values for plant height, position of the first vegetative node and number of vegetative branches/plant as affected by sowing dates and planting pattern in 2013 and 2014 summer seasons

\begin{tabular}{|c|c|c|c|c|c|c|}
\hline \multirow[t]{2}{*}{ Treatments } & \multicolumn{2}{|c|}{ Plant height (cm) } & \multicolumn{2}{|c|}{$\begin{array}{l}\text { Position of the first } \\
\text { vegetative node }(\mathrm{cm})\end{array}$} & \multicolumn{2}{|c|}{$\begin{array}{c}\text { Number of vegetative } \\
\text { branches/ plant }\end{array}$} \\
\hline & $S_{1}(2013)$ & $S_{2}(2014)$ & $S_{1}(2013)$ & $S_{2}(2014)$ & $S_{1}(2013)$ & $S_{2}(2014)$ \\
\hline \multicolumn{7}{|l|}{ Sowing dates } \\
\hline $\mathrm{D}_{1}: 1^{\mathrm{st}}$ April & $150.24 \mathrm{a}$ & $152.377 \mathrm{a}$ & $20.80 \mathrm{a}$ & $21.13 \mathrm{a}$ & $2.978 \mathrm{a}$ & $3.42 \mathrm{ab}$ \\
\hline $\mathrm{D}_{2}:$ Mid April & $124.86 \mathrm{~b}$ & $128.04 \mathrm{~b}$ & $17.22 \mathrm{~b}$ & $17.84 \mathrm{~b}$ & $2.822 \mathrm{a}$ & $2.93 \mathrm{~b}$ \\
\hline $\mathrm{D}_{3}: 1^{\text {st }}$ May & $81.77 \mathrm{c}$ & $81.66 \mathrm{c}$ & $14.511 \mathrm{~b}$ & $15.2 \mathrm{~b}$ & $1.755 \mathrm{~b}$ & $3.84 \mathrm{a}$ \\
\hline L.S.D $D_{0.05}$ & 7.31 & 5.41 & 3.28 & 3.02 & 0.72 & 0.8 \\
\hline \multicolumn{7}{|l|}{ Planting Pattern } \\
\hline $\mathrm{P}_{1}$ : Rows & $121.35 \mathrm{a}$ & $121.82 \mathrm{a}$ & $18.48 \mathrm{a}$ & $18.66 \mathrm{a}$ & $2.24 \mathrm{~b}$ & $3.18 \mathrm{a}$ \\
\hline $\mathrm{P}_{2}$ : Wide ridge in 2 sides & $117.88 \mathrm{a}$ & $121.28 \mathrm{a}$ & $16.11 \mathrm{~b}$ & $16.75 \mathrm{a}$ & $2.88 \mathrm{a}$ & $3.64 \mathrm{a}$ \\
\hline $\mathrm{P}_{3}$ : wide ridges in 2 sides and the top & $117.64 \mathrm{a}$ & $118.97 \mathrm{a}$ & $17.93 \mathrm{ab}$ & $18.75 \mathrm{a}$ & $2.42 \mathrm{ab}$ & $3.36 \mathrm{a}$ \\
\hline L.S.D ${ }_{0.05}$ & 7.16 & 7.62 & 2.12 & 2.66 & 0.41 & 0.56 \\
\hline
\end{tabular}

*, Means at the same column followed by same letter(s) are not significantly different at 0.05 probability level. 
Table 2. Mean values for plant height, position of the first vegetative node and number of vegetative branches/plant as affected by the interaction between sowing dates and planting patterns in 2013 and 2014 summer seasons

\begin{tabular}{|c|c|c|c|c|c|c|c|}
\hline \multirow[t]{2}{*}{ Dates } & \multirow[t]{2}{*}{$\begin{array}{c}\text { Planting } \\
\text { Pattern }\end{array}$} & \multicolumn{2}{|c|}{ Plant height $(\mathrm{cm})$} & \multicolumn{2}{|c|}{$\begin{array}{l}\text { Position of the first } \\
\text { vegetative node }(\mathrm{cm})\end{array}$} & \multicolumn{2}{|c|}{$\begin{array}{c}\text { Number of vegetative } \\
\text { branches/ plant }\end{array}$} \\
\hline & & $S_{1}(2013)$ & $S_{2}(2014)$ & $S_{1}(2013)$ & $S_{2}(2014)$ & $S_{1}(2013)$ & $S_{2}(2014)$ \\
\hline \multirow[t]{3}{*}{$\mathrm{D}_{1}$} & $\mathrm{P}_{1}$ & 162.66 & 162.66 & 21.86 & 21.13 & 2.13 & 2.60 \\
\hline & $\mathrm{P}_{2}$ & 143.00 & 147.46 & 20.06 & 21.06 & 3.86 & 4.46 \\
\hline & $\mathrm{P}_{3}$ & 145.06 & 147.00 & 20.46 & 21.20 & 2.46 & 3.20 \\
\hline \multirow[t]{3}{*}{$\mathrm{D}_{2}$} & $\mathrm{P}_{1}$ & 121.93 & 125.80 & 14.80 & 15.20 & 1.93 & 3.16 \\
\hline & $\mathrm{P}_{2}$ & 121.53 & 126.66 & 15.73 & 16.33 & 1.60 & 2.73 \\
\hline & $\mathrm{P}_{3}$ & 131.13 & 131.66 & 21.13 & 22.0 & 1.73 & 2.90 \\
\hline \multirow[t]{3}{*}{$\mathrm{D}_{3}$} & $\mathrm{P}_{1}$ & 79.46 & 77.00 & 18.80 & 19.66 & 2.66 & 3.80 \\
\hline & $\mathrm{P}_{2}$ & 88.40 & 89.73 & 12.53 & 12.86 & 3.20 & 3.73 \\
\hline & $\mathrm{P}_{3}$ & 77.40 & 78.26 & 12.20 & 13.06 & 3.06 & 4.00 \\
\hline L.S.D $D_{0.05}$ & & 12.40 & 13.209 & 3.66 & 4.62 & 0.7116 & 0.26 \\
\hline
\end{tabular}

Table 3. Mean values for position of the first fruiting node, earliness (\%) as affected by sowing dates and planting pattern in 2013 and 2014 summer seasons

\begin{tabular}{|c|c|c|c|c|}
\hline \multirow[t]{2}{*}{ Treatments } & \multicolumn{2}{|c|}{$\begin{array}{l}\text { Position of the first fruiting node } \\
(\mathrm{cm})\end{array}$} & \multicolumn{2}{|c|}{ Earliness (\%) } \\
\hline & $S_{1}(2013)$ & $S_{2}(2014)$ & $S_{1}(2013)$ & $S_{2}(2014)$ \\
\hline \multicolumn{5}{|l|}{ Sowing dates } \\
\hline $\mathrm{D}_{1}: 1^{\text {st }}$ April & $34.66 \mathrm{a}$ & $35.33 \mathrm{a}$ & $72.44 \mathrm{a}$ & $71.00 \mathrm{a}$ \\
\hline $\mathrm{D}_{2}$ : Mid April & $25.55 \mathrm{~b}$ & $25.73 \mathrm{~b}$ & $62.88 \mathrm{~b}$ & $60.11 \mathrm{~b}$ \\
\hline $\mathrm{D}_{3}: 1^{\text {st }}$ May & $19.53 \mathrm{c}$ & $21.13 \mathrm{c}$ & $59.55 \mathrm{c}$ & $60.11 \mathrm{~b}$ \\
\hline L.S.D 0.05 & 4.35 & 2.74 & 2.51 & 6.55 \\
\hline \multicolumn{5}{|l|}{ Planting Pattern } \\
\hline $\mathrm{P}_{1}$ : Rows & $26.288 \mathrm{a}$ & $26.95 \mathrm{a}$ & $69.00 \mathrm{a}$ & $69.22 \mathrm{a}$ \\
\hline $\mathrm{P}_{2}:$ Wide ridge in 2 sides & $25.82 \mathrm{a}$ & $27.46 \mathrm{a}$ & $62.55 \mathrm{~b}$ & $62.55 \mathrm{ab}$ \\
\hline $\mathrm{P}_{3}$ : wide ridges in 2 sides and the top & $27.64 \mathrm{a}$ & $27.77 \mathrm{a}$ & $63.33 \mathrm{~b}$ & $59.44 \mathrm{~b}$ \\
\hline L.S.D 0.05 & 1.97 & 3.17 & 5.02 & 7.21 \\
\hline
\end{tabular}

*, Means at the same column followed by same letter(s) are not significantly different at 0.05 probability level.

Table 4. Position of the first fruiting node as affected by the interaction between sowing dates and planting patterns in 2013 and 2014 summer seasons

\begin{tabular}{|c|c|c|c|c|c|}
\hline \multirow[t]{2}{*}{ Dates } & \multirow{2}{*}{$\begin{array}{c}\text { Planting } \\
\text { Pattern }\end{array}$} & \multicolumn{2}{|c|}{ Position of the first fruiting node } & \multicolumn{2}{|c|}{ Earliness (\%) } \\
\hline & & $S_{1}(\mathbf{2 0 1 3})$ & $S_{2}(2014)$ & $\mathrm{S}_{1}(\mathbf{2 0 1 3})$ & $S_{2}(2014)$ \\
\hline \multirow[t]{3}{*}{$\mathrm{D}_{1}$} & $\mathrm{P}_{1}$ & 31.20 & 31.73 & 57.00 & 60.00 \\
\hline & $\mathrm{P}_{2}$ & 37.00 & 38.06 & 61.33 & 65.67 \\
\hline & $\mathrm{P}_{3}$ & 35.80 & 36.20 & 60.33 & 54.67 \\
\hline \multirow[t]{3}{*}{$\mathrm{D}_{2}$} & $\mathrm{P}_{1}$ & 23.80 & 24.73 & 62.00 & 59.33 \\
\hline & $\mathrm{P}_{2}$ & 23.33 & 24.46 & 65.67 & 63.00 \\
\hline & $\mathrm{P}_{3}$ & 29.53 & 28.00 & 61.00 & 58.00 \\
\hline \multirow[t]{3}{*}{$\mathrm{D}_{3}$} & $\mathrm{P}_{1}$ & 23.86 & 24.40 & 68.67 & 68.33 \\
\hline & $\mathrm{P}_{2}$ & 17.13 & 19.86 & 80.00 & 79.00 \\
\hline & $\mathrm{P}_{3}$ & 17.60 & 19.13 & 68.67 & 65.67 \\
\hline \multicolumn{2}{|c|}{ L.S.D 0.05} & 3.416 & 5.5 & N.S & N.S \\
\hline \multicolumn{3}{|c|}{$\begin{array}{l}\text { Earliness index was not affected by the interaction } \\
\text { between the two studied factors. It appears that the taller } \\
\text { plants, elevated position of the first vegetative node, the } \\
\text { higher number of vegetative branches/ plant, elevated } \\
\text { position of the first fruiting node and late maturity are } \\
\text { all consequences of a relatively long growing season }\end{array}$} & $\begin{array}{l}\text { with coole } \\
\text { establishme } \\
\text { April, as } \\
\text { reduction } \\
\text { sowing we } \\
\text { Giza } 86 \text { in }\end{array}$ & $\begin{array}{l}\text { atures preva } \\
\text { egetative gl } \\
\text { to the la } \\
\text { leight and } \\
\text { served by } \mathrm{S} \\
\text { lso, El-Tabb }\end{array}$ & $\begin{array}{l}\text { during seed } \\
\text { stages early } \\
\text { y sowing. } \\
\text { s with dela } \\
\text { et al. (2012 } \\
001) \text { report }\end{array}$ \\
\hline
\end{tabular}


similar decrease in earliness index of about $16 \%$ with delayed sowing from April $1^{\text {st }}$ to May $1^{\text {st }}$.

\section{II- Yield and yield components:}

Sowing dates, planting patterns and their interactions had significant effects on weight of seed cotton/plant and number of bolls/plant in both growing seasons (Tables 6 \& 7). Only the main effects significantly affected weight of bolls but not their interactions (Table 6). Delayed sowing significantly reduced weight of seed cotton/plant from $58.91 \mathrm{~g} /$ plant in $1^{\text {st }}$ April sowing to $33.95 \mathrm{~g} /$ plant in $1^{\text {st }}$ May sowing in the 2013 growing season and from $60.79 \mathrm{~g} / \mathrm{plant}$ to $36.58 \mathrm{~g} / \mathrm{plant}$ in the 2014 growing season. In addition, a significant reduction in number of bolls/plant was recorded in both seasons (Table 5). The weight of bolls was least affected by the date of sowing. On the other hand, the planting pattern significantly affected seed cotton yield/plant in the first season with $\mathrm{P}_{1}$ giving significantly high values $(51.63 \mathrm{~g})$ than the other planting patterns.

The highest seed cotton yield was observed for the early sowing date ( $1^{\text {st }}$ April) using the standard growing method, with plants grown on one side of ridge only and $25 \mathrm{~cm}$ between hills $\left(\mathrm{P}_{1}\right)$, especially in the first season. Sowing on April $1^{\text {st }}$ with the growing patterns $\mathrm{P}_{1}$ and $\mathrm{P}_{3}$ were superior in yield to any other growing dates and growing pattern (Table 6). However, the standard growing pattern $\left(\mathrm{P}_{1}\right)$ was $39 \%$ higher than $\left(\mathrm{P}_{3}\right)$ in the first season and $27 \%$ higher in the second season, in the $1^{\text {st }}$ April sowing date. The increase in seed cotton yield/plant appears to be an outcome of an increase in number of bolls/plant rather than to boll weight (Table 5).

Table 5. Mean values for seed cotton yield (g)/plant, number of bolls/plant and boll weight (g) as affected by sowing dates and planting pattern in 2013 and 2014 summer seasons

\begin{tabular}{|c|c|c|c|c|c|c|}
\hline \multirow[t]{2}{*}{ Treatments } & \multicolumn{2}{|c|}{$\begin{array}{c}\text { Seed cotton yield } \\
(\mathrm{g}) / \mathrm{plant}\end{array}$} & \multicolumn{2}{|c|}{ Number of bolls/plant } & \multicolumn{2}{|c|}{ Boll weight (g) } \\
\hline & $S_{1}(2013)$ & $S_{2}(2014)$ & $S_{1}(2013)$ & $S_{2}(2014)$ & $S_{1}(2013)$ & $S_{2}(2014)$ \\
\hline \multicolumn{7}{|l|}{ Sowing dates } \\
\hline $\mathrm{D}_{1}: 1^{\text {st }}$ April & $58.91 \mathrm{a}$ & $60.79 \mathrm{a}$ & $25.88 \mathrm{a}$ & $27.6 \mathrm{a}$ & $2.26 \mathrm{a}$ & $2.40 \mathrm{a}$ \\
\hline $\mathrm{D}_{2}$ : Mid April & $44.05 \mathrm{~b}$ & $49.14 b$ & $19.26 \mathrm{~b}$ & $20.44 \mathrm{~b}$ & $2.27 \mathrm{a}$ & $2.22 \mathrm{ab}$ \\
\hline $\mathrm{D}_{3}: 1^{\mathrm{st}}$ May & $33.95 \mathrm{c}$ & $36.58 \mathrm{c}$ & $16.35 \mathrm{c}$ & $16.28 \mathrm{c}$ & $2.21 \mathrm{a}$ & $2.07 \mathrm{~b}$ \\
\hline $\mathrm{D}_{1}: 1^{\text {st }}$ April & 7.11 & 9.23 & 3.10 & 3.43 & 0.092 & 0.251 \\
\hline \multicolumn{7}{|l|}{ Planting Pattern } \\
\hline $\mathrm{P}_{1}$ : Rows & $51.63 \mathrm{a}$ & $53.07 \mathrm{a}$ & $22.511 \mathrm{a}$ & $22.88 \mathrm{a}$ & $2.27 \mathrm{a}$ & $2.28 \mathrm{a}$ \\
\hline $\mathrm{P}_{2}:$ Wide ridge in 2 sides & $42.38 \mathrm{~b}$ & $43.39 \mathrm{a}$ & $18.57 \mathrm{a}$ & $19.62 \mathrm{a}$ & $2.28 \mathrm{a}$ & $2.19 \mathrm{a}$ \\
\hline $\begin{array}{l}\mathrm{P}_{3} \text { : wide ridges in } 2 \text { sides and the } \\
\text { top }\end{array}$ & $42.89 \mathrm{~b}$ & $50.04 \mathrm{a}$ & $19.422 \mathrm{a}$ & $21.82 \mathrm{a}$ & $2.19 \mathrm{a}$ & $2.21 \mathrm{a}$ \\
\hline L.S.D ${ }_{0.05}$ & 7.73 & 12.01 & 4.14 & 5.23 & 0.242 & 0.339 \\
\hline
\end{tabular}

*, Means at the same column followed by same letter(s) are not significantly different at 0.05 probability level.

Table 6. Mean values for seed cotton yield (g)/plant, number of bolls/plant and boll weight (g) as affected by the interaction between sowing dates and planting patterns in 2013 and 2014 summer seasons

\begin{tabular}{lccccc}
\hline Dates & Pattern & \multicolumn{2}{c}{ Seed cotton yield (g)/plant } & \multicolumn{2}{c}{ Number of bolls/ plant } \\
\cline { 2 - 5 } & & $\mathbf{S}_{\mathbf{1}}(\mathbf{2 0 1 3})$ & $\mathbf{S}_{\mathbf{2}}(\mathbf{2 0 1 4})$ & $\mathbf{S}_{\mathbf{1}}(\mathbf{2 0 1 3})$ & $\mathbf{S}_{\mathbf{2}}(\mathbf{2 0 1 4})$ \\
\hline $\mathrm{D}_{1}$ & $\mathrm{P}_{1}$ & 83.36 & 78.77 & 34.73 & 33.86 \\
& $\mathrm{P}_{2}$ & 42.80 & 46.06 & 19.86 & 20.86 \\
& $\mathrm{P}_{3}$ & 50.58 & 57.55 & 23.06 & 28.06 \\
$\mathrm{D}_{2}$ & $\mathrm{P}_{1}$ & 40.10 & 51.20 & 19.06 & 20.33 \\
& $\mathrm{P}_{2}$ & 46.57 & 49.96 & 19.93 & 21.46 \\
& $\mathrm{P}_{3}$ & 45.48 & 46.26 & 18.80 & 19.53 \\
$\mathrm{D}_{3}$ & $\mathrm{P}_{1}$ & 31.45 & 29.26 & 13.73 & 14.46 \\
& $\mathrm{P}_{2}$ & 37.79 & 34.16 & 15.93 & 16.53 \\
& $\mathrm{P}_{3}$ & 32.62 & 46.31 & 16.40 & 17.86 \\
L.S.D & & 13.40 & $\mathrm{~N} . \mathrm{S}$ & 0.703 & 0.855 \\
\hline
\end{tabular}




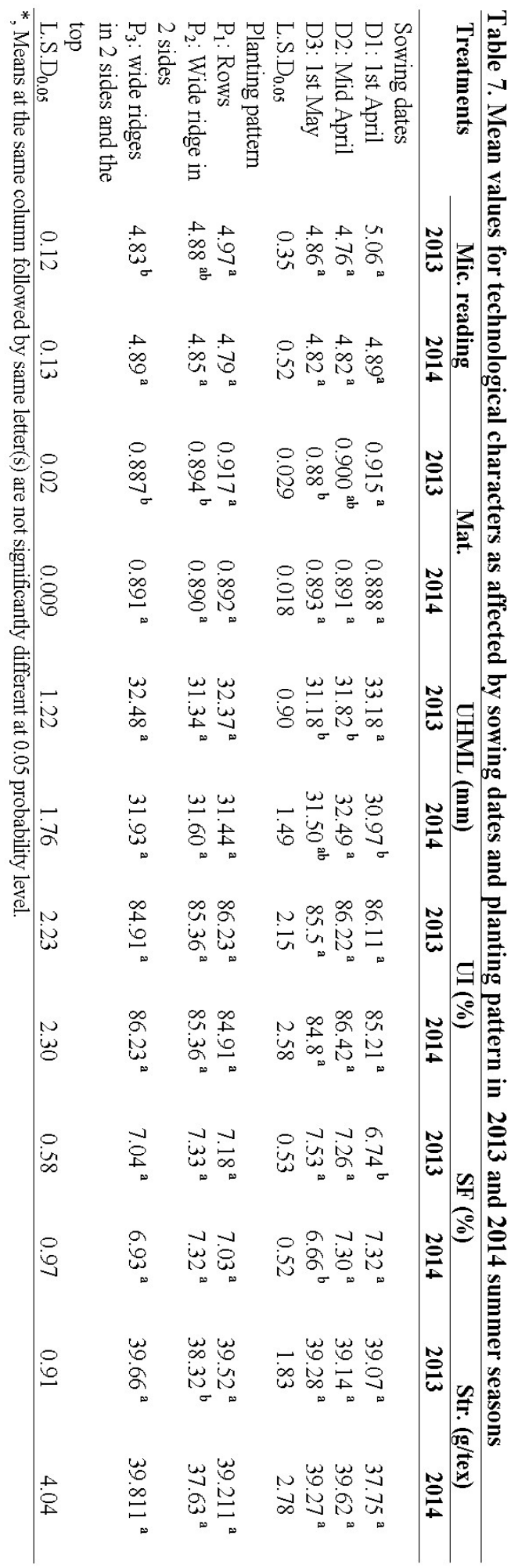


Table 8. Mean values for technological characters as affected by the interaction between sowing dates and planting patterns in 2013 and 2014 summer seasons

\begin{tabular}{|c|c|c|c|c|c|c|c|c|}
\hline \multirow[t]{2}{*}{ Dates } & \multirow[t]{2}{*}{ Pattern } & \multicolumn{2}{|c|}{ Mic. reading } & \multicolumn{2}{|c|}{ Mat. } & \multirow{2}{*}{$\begin{array}{c}\text { UHML (mm) } \\
2014\end{array}$} & \multirow{2}{*}{$\begin{array}{c}\text { SF (\%) } \\
2014\end{array}$} & \multirow{2}{*}{$\begin{array}{c}\text { Str. }(\mathrm{g} / \mathrm{tex}) \\
2014\end{array}$} \\
\hline & & 2013 & 2014 & 2013 & 2014 & & & \\
\hline \multirow{3}{*}{$\mathrm{D}_{1}$} & $\mathrm{P}_{1}$ & 5.23 & 5.08 & 0.89 & 0.89 & 31.49 & 7.05 & 41.76 \\
\hline & $\mathrm{P}_{2}$ & 5.04 & 5.01 & 0.913 & 0.89 & 30.58 & 7.73 & 37.53 \\
\hline & $\mathrm{P}_{3}$ & 4.91 & 4.58 & 0.89 & 0.88 & 31.47 & 7.06 & 37.93 \\
\hline \multirow[t]{3}{*}{$\mathrm{D}_{2}$} & $\mathrm{P}_{1}$ & 4.42 & 4.50 & 0.88 & 0.886 & 33.37 & 6.60 & 37.86 \\
\hline & $\mathrm{P}_{2}$ & 4.72 & 4.75 & 0.87 & 0.890 & 31.61 & 6.90 & 39.73 \\
\hline & $\mathrm{P}_{3}$ & 5.13 & 5.20 & 0.90 & 0.896 & 34.57 & 6.73 & 39.83 \\
\hline \multirow[t]{3}{*}{$\mathrm{D}_{3}$} & $\mathrm{P}_{1}$ & 4.83 & 4.80 & 0.89 & 0.893 & 32.24 & 7.90 & 38.93 \\
\hline & $\mathrm{P}_{2}$ & 4.87 & 4.80 & 0.89 & 0.890 & 31.82 & 7.36 & 37.70 \\
\hline & $\mathrm{P}_{3}$ & 4.88 & 4.88 & 0.95 & 0.896 & 31.40 & 7.33 & 41.23 \\
\hline L.S.D $D_{0.05}$ & & 0.184 & 0.23 & 0.035 & 0.015 & 2.07 & 1.01 & 1.57 \\
\hline
\end{tabular}

The results on yield and yield components presented here are in harmony with the results of Sultan et al. (2012). A reduction in seed cotton yield/plant between (25 and 19\%) was observed in our study when sowing was delayed from $1^{\frac{\text { st }}{t}}$ April to $1^{\text {st }}$ May in the two seasons, respectively as compared to 6 and $17 \%$ in the study of Sultan et al. (2012) for the same cultivar in the two studied seasons, respectively. As to boll weight, sowing date had minimal effects on the trait in both studies. Delayed sowing causes reduction in seed cotton yield due to a reduction in the period necessary for full boll growth and maturity and also less favorable conditions for boll maturity (Nawar et al. 1986, Barradas and Lopez-Bellido, 2009 and Soomro et al., 2014) and higher bollworm infestation (El-Tabbakh, 2001).

As to the effect of sowing date and planting pattern on the technological characters of cotton fiber, it was observed that planting dates had significant effects on fiber maturity in the first season only, UHML and SF\% in both seasons, while Mic. reading, UI and Strength (g/tex) were not affected. The planting pattern on the other hand, had only significant effects on Mic. reading, Mat. and strength in the $1^{\text {st }}$ season only. The highest Mic. reading was observed for $1^{\text {st }}$ April sowing date with the standard planting pattern $\left(\mathrm{P}_{1}\right)$ in both seasons, due to higher maturity of fibers.

Our results on technological characters of cotton fiber indicated a reduction in Mic. reading, maturity, UI and strength for both seasons with delay in sowing date (Table 7 and 8). On the other hand UHML and SF\% were significantly affected by sowing date. As to planting patterns, only in the season of 2014 (Table 7 and 8) were significant variations observed for Mic. reading, maturity and strength, indicating less importance of planting pattern on technological characters. This is not in general agreement with Hons and McMichael (1986), where planting pattern affected Mic. reading and staple length. Also Soomro et al. (2014) and Ali et al. (2009), working on G. hirsutum, observed effects for planting pattern on Mic. reading. However, El-Tabbakh (2001), working on $G$. barbadense, and Barradas and Lopez-Bellido (2009) working on G. hirsutum, observed no effects of sowing date on Mic. reading.

Based on the previous results, it was observed that effects of planting date were more pronounced on the studied phenological characters, yield and yield components than the planting patterns. The fiber technological traits including micronaire reading, fiber maturity, fiber upper half mean length (UHML), uniformity index (UI), short fiber (SF) and fiber strength (Str.) were least affected by either planting dates or planting patterns. Results suggest that growing cotton on the $1^{\text {st }}$ of April is more suitable than delayed sowing for the cultivar Giza 86 and that the standard sowing of seeds on one side of the ridge, in hills $25 \mathrm{~cm}$ apart, resulted in better growth characters and highest yields. Also growing cotton on the wide ridges of the preceding wheat crop is not recommended as it resulted in reduction in yield and its components.

\section{REFERENCES}

Aasim, M., E.M. Omer and A. Karim. 2008. Yield and competition indices of intercropping cotton (Gossypium hirsutum L.) using different planting patterns. Tarim Bilimleri Dergisi, 14(4): 326-333.

Ahmed, S., S. Ahmad, M. Ashraf, N.Ul-Eslamkhan and N. Iqbal. 2008. Assessment of yield related morphological measures for earliness in upland cotton (Gossypium hirsutum L.). Pak. J. Bot., 40(3): 1201-1207.

Ahmed, M.E., O. Adbalrasol and M.F. Ahmed. 2013. Growth and yield of seed cotton in response to plant spacing and weeding frequency under flood irrigation. J. Renewable Agric., 1(3): 27-32.

Ali, H., M.N. Afzal, S. Ahmed and D. Muhammad. 2009. Effect of cultivars and sowing dates on yield and quality of Gossypium hirsutum L. crop. Journal of Food, Agriculture \& Environment, Vol. 7(3\&9): 244-247. 
Baker, S.H. (1976). Response of cotton to row patterns and plant populations. Agr. J. 68(1): 85-88.

Barradas, G. and R.J. Lopez-Bellido. 2009. Genotype and planting date effects on cotton growth and production under South Portugal conditions. III-Boll set percentage, boll location, yield and lint quality. J. Food, Agric. Environ., 7(2): 322-328.

Din, M.A. Ali, S. Sabir and L. Ali. 2004. Cotton yield as influenced by different sowing dates under the climatic conditions of Vehari-Pakistan. International J. Agric. Bio., 6(4): 644- 646.

Dong, H., W. Li, W. Zhenhuaili, D. Zhang and Y. Niu. 2006. Yield, quality and leaf senescence of cotton grown at varying planting dates and plant densities in the yellow River Valley of China. Field Crop Res., 98: 106-115.

El-Hariry, S. H. M. 1986. Genetic analysis of yield characters and fiber properties under different sowing dates. $\mathrm{Ph}$. D. Thesis Fac. Agric. Ain Shams Univ. Egypt.

El-Tabbakh, S. Sh. 2001. Effect of sowing dates and plant density on seed cotton yield and its components, earliness criteria and fiber properties of two cotton cultivars (Gossypium spp.). Alex. J. Agri. Res., 46(3): 47-60.

Gomez, K. A. and A. A. Gomez. 1984. Statistical Procedures for Agricultural Research. John Wiley \& Sons New York, USA.

Hons, F.M. and B.L. McMichael. 1986. Planting pattern effects on yield water use and root growth of cotton. Field Crops Res., 13: 147-158.
Nadeem, M.A., A. Ali, M. Tahir, M. Naeem, A.R. Chadhar and S. Ahmed. 2010. Effect of nitrogen levels and plant spacing on growth and yield of cotton. Pakistan J. L. Soc. Sci., 8(2): 121-124.

Nawar, A.I., A.A. Kassem, M.A. Bishr and F.H. Khadr. 1986. Sowing cotton after berseem and relay cropping with onions Egyptian. Society of Crop Science, Vol. 2: 299308.

SAS Institute, Inc. 2007. SAS Technical Report SAS/STAT Software; Changes and Enhancements Users Guide. Volume 2, Version 9.1.3, Forth Edition, Cary, Nc: SAS Institute.

Shafshak K. S., A. A. Sallam, M. K. Khalifa and M. M. Awaad. 1987. Effect of planting date on yield components and lint properties of some cotton varieties. Agric. Res. Rev., 65(4): 575-587.

Shalaby, E.M.M. 1972. Physiological response of cotton plants to planting date and population density. PH. D. Thesis, Fac. of Agric., Ain Shams Univ., Egypt.

Showler, A.T., S.M. Greenberg, A.W. Scott and J.RC. Robinson. 2005. Effects of planting dates on boll weevils (Coleopteran uculionidae) and cotton fruit in the subtropics. J. Econ. Entomology, 98(3): 796-804.

Soomro, A.W., F.H. Panhwar, A.R. Channa, M.Z. Ahsan, M.S. Majidano, F.I. Khaskheli and K.B. Sial. 2014. Effects of sowing time on yield, got and fiber traits of upland cotton (Gossypium hirsutum L.). International J. of Scientific \& Engineering Res., Vol. 5(12): 194-198.

Sultan, M.S., A.T. EL-Kassaby, M.H. Ghonema, A.A. Ogeaz and A.M. Abd-Allah. 2012. Relay intercropping wheat and cotton studies: Effect of sowing dates and ridge width on cotton. J. of Biological Sci., 12(6): 349-354. 


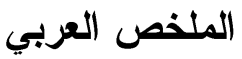

\section{دراسة تأثثير مواعيد ونظم الزراعة على النمو والإنتاجية والصفات التكنولوجية لمحصول القطن صنف}

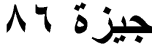

محمود حسن عبد المنعم عبد الحفيظ، محسن آدم عمر، سامى شعبان الطباخ، على عيسى نوار

النتائج أن ميعاد الزر اعة كان له الثأثير الأكبر على الصفات

الفينولوجية وصفات المحصول ومكوناته مقارنة بنظم الزراعة تحت الدراسة بالنسبة للصفات النكنولوجية ومنها

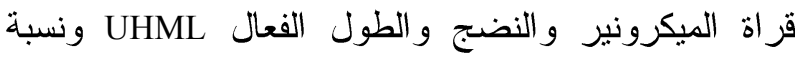
الإنتظامية UI ونسبة الثعير ات القصبرة SF ومتانة الثعرة Str. فإنها لم تتأثر بشدة بمواعيد الزراعة أونظم الزراعة الفيرة

$$
\text { تحت الدر اسة. }
$$

أوضحت النتائج أن ميعاد الزراعة المبكر (أول إبريل)

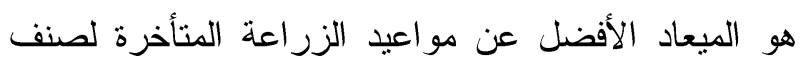

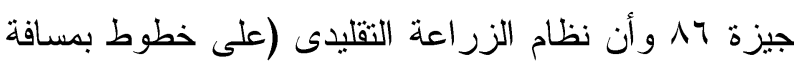
O ro سم بين الجور) أعطى أفضل صفات للنمو و المحصول. كذللك أوضحت النتائج أن الزراعة على مصاطب القمح

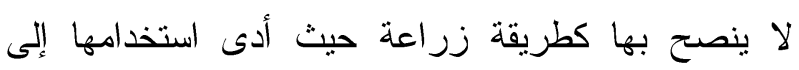
انخفاض المحصول ومكوناته.
أجريت الدراسة فى محطة البحوث الزراعية محطة

البحوث الزر اعية- جامعة الإسكندرية باستخدام صنف قطن

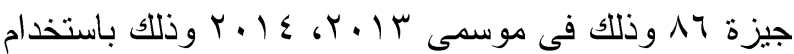
تصميم القطع المنشقة مرة واحدة فى ثلاث مكررات حيث

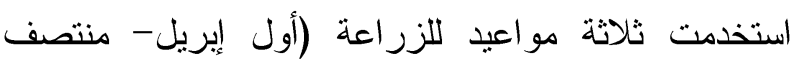

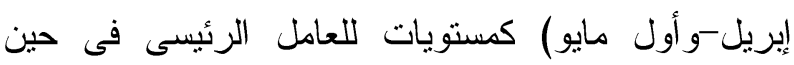
استخدمت ثلاثة نظم للزراعة (الزراعة على ريشة واحدة

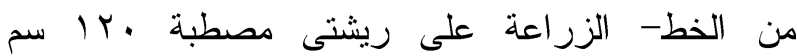

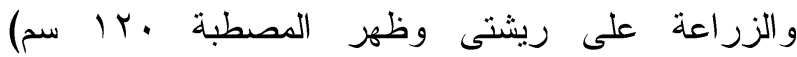
كمستويات للعامل الفرعى لدراسة نأثير مواعيد الزراعة ونظم الزراعة المختلفة على نمو وإنتاجية وجودة ألياف

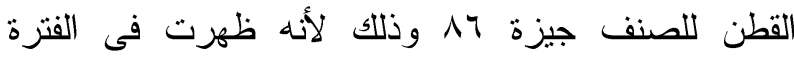
السابقة إتجاهات زراعة غير مدروسة أدت للفلاح بتأخير زراعة القطن بعد محصول القمح وكذلك زراعة القطن على مصاطب القمح دون تجهيز للتربة. ولقد أظهرت 